АРТЕЕВ Сергей Павлович - кандидат политических наук, старший преподаватель кафедрымировых политических процессов МГИМО МИД России (119454, Россия, г. Москва, пр-кт Вернадского, 76); научный сотрудник Национального исследовательского института мировой экономики и международных отношений им. Е.М. Примакова РАН (117997, Россия, г. Москва, Профсоюзная ул., 23; artsp7@yandex.ru)

\title{
ПАНДЕМИЯ COVID-19: КОНСПИРОЛОГИЯ И АНТИКОНСПИРОЛОГИЯ
}

\begin{abstract}
Аннотация. COVID-19 - это не только пандемия нового опасного коронавируса, но и время расцвета конспирологических теорий. Несмотря на то что теория заговора стала одной из наиболее обсуждаемых тем в общественно-политическом дискурсе задолго до 2020-2022 гг., конспирология как феномен для анализа в российской политологии пока представлена слабо. Российские исследования не отличает систематичность и достаточная полнота охвата. Данная статья отчасти стремится заполнить эту лакуну. Автор отвечает на вопросы, почему ковидные теории заговора сумели завоевать такую популярность и как они продлевают пандемию, влияя на политические процессы.

Ключевые слова: конспирология, теория заговора, пандемия, COVID-19, вакцинация, чипирование
\end{abstract}

Введение. Пандемия COVID-19 уже несколько лет определяет траекторию мирового развития и оказывает существенное воздействие на общественнополитическую ситуацию. На этом фоне конспирология стала значимой частью публичного дискурса практически повсеместно. Хотя в последнее время за рубежом стали появляться обобщающие труды [Routledge Handbook... 2020; Harambam 2020; The Social Psychology... 2019], в российских политологических исследованиях конспирология как предмет научного анализа пока занимает периферийное положение. Отчасти данную лакуну заполняют исследования в смежных сферах - социологии [Хохлов 2020], антропологии [Панченко 2015] и психологии [Мягков и др. 2021; Михеев, Нестик 2021]. Между тем пандемия COVID-19 убедительно демонстрирует, что политическое влияние конспирологических теорий становится особенно опасным в случае возникновения внезапного масштабного вызова, особенно по типу «черного лебедя». Почему ковидные теории заговора сумели завоевать такую популярность, и как они продлевают пандемию, влияя на политические процессы?

Терминологические пояснения. С целью предотвращения двусмысленности необходимо пояснить используемую лексику. Теория заговора (конспирология) - интерпретация значимых масштабных событий или процессов как следствия злонамеренного предварительного сговора группы лиц при отсутствии веских фактологических доказательств в пользу такой трактовки. Наиболее яркий пример - наличие среди мировой политической элиты инопланетной расы рептилоидов, которые якобы и управляют Землей. Такой подход следует отличать от действительно имевших место событий преступного характера, происшедших в результате заговора. Например, римский военачальник Гай Юлий Цезарь на самом деле был убит вследствие заговора группы сенаторов. Кроме того, существует еще и обширная серая зона, когда характер имеющихся сведений не позволяет прийти к четкому однозначному заключению. В качестве иллюстрации серой зоны подходит тайна смерти высокопоставленного нацистского преступника Мартина Бормана или события в Казахстане в начале января 2022 г.

Предпосылки ковидных теорий заговора. Существуют как минимум пять предпосылок для расцвета конспирологических теорий ковидной эпохи. 
1. Эволюционно-психологический атавизм. Вера людей в теории заговора отчасти может быть объяснена некоторыми механизмами функционирования человеческой психики. В первобытные времена человек был слабо защищен от многочисленных природных опасностей, поэтому с точки зрения выживания, например, шорох в кустах было полезнее воспринимать как признак присутствия опасного хищника, нежели как обычный и безопасный порыв ветра. Однако этот первобытный механизм не предусматривает глубокого анализа ситуации, а ориентирован на бегство, т.е. принятие быстрого решения без какой-либо рефлексии. Такой способ реагирования при срабатывании применительно к политическим событиям вместо стадии бегства приводит к ошибочному выводу о злонамеренном характере происшедшего. Далее подключается фантазия и начинается конструирование мыслительных схем под идею о том, «что происходит на самом деле».

2. Информационный взрыв. К началу 2020-х гг. в мире стал формироваться новый технологический уклад. В то же время среднестатистический житель планеты явно отстает от вызовов времени. На фоне резко усилившихся по объемам и ускорившихся в единицу времени медиапотоков создается типичная ситуация невозможности для подавляющего большинства людей критически оценивать получаемые данные. Критическое мышление по-прежнему не стало ключевой компетенцией человека вне зависимости от его рода занятий.

3. Политика как черный ящик. Возникающие время от времени политические скандалы, утечки чувствительной информации в СМИ (разоблачения Wikileaks) и классические переговоры политиков тет-а-тет неизбежно порождают в обществе неофициальные версии о политических процессах. Недостаток транспарентности власти выступает драйвером теории заговора. В целом производство фейковых новостей стало индустрией. Более того, политические элиты сознательно формируют среду постправды как инструмента управления [Чугров 2017].

4. Большая наука и маленький человек. Стремление человека сформировать в своем сознании понятную непротиворечивую картину мира является базовым, почти рефлекторным. В то же время развитие науки происходит настолько быстро, что в силу объективных психофизиологических и других ограничений большинство людей не в состоянии сформировать глубокие познания хотя бы по нескольким направлениям. В результате сегодня люди делегируют экспертам в соответствующих областях формирование своего отношения ко многим ключевым вопросам жизни. Однако далеко не все эксперты действуют в интересах общества.

5. Фактор массовой культуры. Конспирология превратилась в важнейший компонент массовой культуры во второй половине XX в. При этом западные, прежде всего американские, теории заговора (наподобие инцидента в Розуэлле в 1947 г. или подоплеки теракта 11 сентября 2001 г.), благодаря «мягкой силе» Голливуда и определяющей роли США в мировых процессах быстро приобрели популярность во всем мире.

Предпосылки сами по себе не порождают конспирологические теории, но формируют климат для их создания и внедрения в общественное сознание. Затем уже многое зависит от актуальной общественной повестки, а сегодня в мире нет ничего более медийного, чем пандемия COVID-19.

Ковидные теории заговора. Можно выделить несколько основных ковидных теорий заговора (далее - КТ3), которые представляют опасность и в медицинском, и в политическом измерении.

KT3 1. Существует ли вирус на самом деле?

Первая ковидная теория заговора связана с отрицанием самого факта суще- 
ствования нового вируса. В числе ковид-диссидентов оказались первые лица государств, правда, периферийных. Хрестоматийным стал случай президента Танзании Джона Магуфули, который, потратив немало сил на борьбу с профилактикой новой инфекции, в конце концов сам пал жертвой COVID-191. Такая позиция первых лиц опасна не только для жителей отдельных государств - в условиях глобальной медиасреды она еще дезориентирует жителей других стран из числа сомневающихся, которых всегда много в ситуации недостатка информации.

КТЗ 2. Ковид - это просто разновидность гриппа.

Эта теория заговора тесно связана с предыдущей с тем отличием, что само существование нового коронавируса и его распространение по миру не отвергается, но при этом новая инфекция якобы не опаснее гриппа и других ОРВИ, поэтому никаких особых мер вводить не требуется. Такой подход означает отказ от соблюдения профилактических мер (локдаун, карантин, социальное дистанцирование, масочный режим и т.п.).

K сожалению, в числе приверженцев такой теории оказались и ведущие мировые политики. Позиция Д. Трампа по коронавирусу ${ }^{2}$ стала уязвимой мишенью для его противника на выборах президента США. Еще более ранним примером здесь выступила Беларусь. А. Лукашенко в марте 2020 г. прямо заявил, что считает происходящее заговором, политическим инструментом и выступает против закрытия границ ${ }^{3}$.

Исходя из имеющихся данных, многие действительно переносят новую болезнь как обычное ОРВИ. Однако также документально установлено, что коварство COVID-19 обусловлено непредсказуемостью болезни - до сих пор нет однозначных ответов на многие вопросы по заражению, развитию и исходу заболевания, особенно в долгосрочной перспективе.

КТ3 3. Кто виноват? (Кто компенсирует ущерб?)

Еще в январе-феврале 2020 г. начались дискуссии и расследования о происхождении коронавируса, но ситуация далека от ясности. Фундаментальный вопрос - имеет ли вирус $S A R S-C o V-2$ естественное (природное) или искусственное (лабораторное) происхождение?

45-й президент США Д. Трамп прямо обвинил Китай и потребовал компенсаций 4 . Многие государства официально заняли выжидательную позицию, т.е. формально не отрицают возможность того, что пандемия - результат применения биологического оружия или следствие халатности. Сегодня это серая зона. Версия о возможной случайной утечке сохраняет свою актуальность.

В то же время вероятность намеренного применения нового коронавируса как биологического оружия не выглядит убедительной. Для Китая это был бы саморазрушительный акт, ведь международная напряженность значительно возросла, а американо-китайские торговые войны вышли на новый виток, не говоря уже о сильном падении внешних рынков, что губительно для экспортно ориентированной экономики КНР.

1 Умер отрицавший наличие в Танзании COVID-19 президент Джон Магуфули.- РБК. 17.03.2021. Доступ: https://www.rbc.ru/rbcfreenews/60526b3a9a794728754c74c4 (проверено 23.01.2022).

2 Твитт Трампа о том, что грипп опаснее коронавируса, пометили какдезинформирующий.

- TACC. 06.10.2020. Доступ: https://tass.ru/obschestvo/9644275 (проверено 23.01.2022).

3 Лукашенко о борьбе с коронавирусом: занимаемся без шума и пыли. - БЕЛТА. 27.03.2020. Доступ: https://www.belta.by/president/view/lukashenko-o-borbe-s-koronavirusomzanimaemsja-bez-shuma-i-pyli-384934-2020/ (проверено 23.01.2022).

4 Дональд Трамп потребовал от Китая репарации в $\$ 10$ трлн за коронавирус. - РИА Новости. 06.06.2021. Доступ: https://ria.ru/20210606/covid-1735838949.html (проверено 23.01.2022). 


\section{КТ3 4. Кому выгодно?}

Новая смертоносная болезнь, охватившая планету, конечно, стала главной темой медико-биологических исследований во всем мире. Однако вирус оказался куда более сложным, чем предыдущие коронавирусы, и дать ему однозначные объективные характеристики с учетом мутаций и появления новых штаммов получается не всегда. В 2021 г. на смену уханьскому пришли новые штаммы, особо следует выделить «дельту» и «омикрон», которые сильно отличаются по своим свойствам от «прародителя», что способствовало появлению очередной волны недоверия к официальным рекомендациям по профилактике и лечению. Так или иначе, но всем стало очевидна ключевая роль фармацевтики в борьбе с пандемией.

В связи с этим в медиапространстве вновь заговорили о фармкомпаниях как главных бенефициарах пандемии ${ }^{1}$. Фарминдустрия отнюдь не бедствовала и до пандемии, при этом развитие происходило в куда более комфортных условиях, а новые прибыльные ниши на рынке появлялись с завидной регулярностью. Тем не менее некоторые фармкомпании в самом деле получили колоссальную прибыль в ходе пандемии ${ }^{2}$.

Однако точно то же происходит в периоды военных конфликтов с обороннопромышленным комплексом. При этом было бы неправильным считать оружейников единственными виновниками войн. Так же и здесь, ведь бенефициар - это не обязательно источник бедствия, а чаще всего тот, кто сумел с выгодой для себя использовать ситуацию, тем более что ни одной из фармкомпаний не удалось занять монопольное положение. Мировой рынок антиковидных вакцин диверсифицирован.

КТЗ 5. Вакцинация - это чипирование.

Согласно оценкам врачей, тотальная вакцинация - единственный способ остановить пандемию и понизить статус нового коронавируса до рядового ОРВИ. Однако появление вакцин во второй половине 2020 г. и глобальная кампания по вакцинации 2021 г. не стали спасением. Люди во многих странах отказываются от прививки, опасаясь так называемого чипирования, что, согласно адептам теории заговора, приводит к последующей утрате контроля над собой ${ }^{3}$. Антиваксеры стали оказывать существенное влияние на социально-экономические и политические процессы, обостряя и уже имеющиеся общественные расколы.

На межгосударственном уровне, вопреки призывам ВО3 и ООН, ведущие страны превратили вакцинную дипломатию в новый фронт противоборства. Ковидная вакцинация превратилась в разновидность торговой войны.

Рассмотренные примеры, конечно, не охватывают все поле конспирологических построений на тему COVID-19, их производство продолжается постоянно. Самое бесполезное, что можно сделать в такой ситуации, - это попытаться ввести запрет на распространение конспирологических теорий, потому

\footnotetext{
${ }^{1}$ Новые рекомендации Минздрава, или почему нас никак не вылечат от Covid-19. - Hoвые известия. 24.09.2021. Доступ: https://newizv.ru/news/society/24-09-2021/novye-rekomendatsiiminzdrava-ili-pochemu-nas-nikak-ne-vylechat-ot-covid-19 (проверено 23.01.2022).

2 Золотая пандемия: прибыль ста крупнейших фармдистрибьюторов выросла в 2020 году практически вдвое. - Forbes. 25.06.2021. Доступ: https://www.forbes.ru/biznes/432995zolotaya-pandemiya-pribyl-sta-krupneyshih-farmdistribyutorov-vyrosla-v-2020-godu (проверено 23.01.2022); Когда горе - не беда: кто выиграл от пандемии. - Деловой Петербург. 30.09.2021. Доступ: https://m.dp.ru/a/2021/09/29/Kogda_gore_ne_beda (проверено 23.01.2022).

3 Чипы в вакцинах: откуда взялась эта теория заговора? Главное о пандемии из зарубежных СМИ. - ТАСС. 11.06.2021. Доступ: https://nauka.tass.ru/nauka/11627465 (проверено 23.01.2022).
} 
что неизбежно произойдет рост популярности ковидной конспирологии, т.к. интерес к тому, что пытаются убрать из публичного доступа, только возрастает.

Прививка от конспирологии. Конспирология функционирует в рамках собственной замкнутой логики. И пренебрежение к фактам - ее важнейшая характеристика. Она потому и теория, что практика ей без надобности. Более того, в рамках конспирологического мышления чем меньше фактов, тем это лучше доказывает наличие заговора, ведь злые силы позаботились о том, чтобы никто ничего не понял и не смог им помещать. Если враг невидим и всесилен, то и бороться с ним бесполезно.

«Пандемия конспирологии» как инфодемия поразила человечество на несколько десятилетий раньше, чем COVID-19. И в России ситуация, к сожалению, не самая благополучная. Например, $49 \%$ россиян считают высадку американцев на Луну фальсификацией ${ }^{1}$. Жертв конспирологических теорий гораздо больше, чем у COVID-19. Однако их труднее подсчитать. Теория заговора как болезнь массового сознания создает серьезные препятствия не только для преодоления кризисных ситуаций, но и для ответственного развития человечества как вида. Это хорошо видно на примере не/реализации климатической и экологической повестки.

Расцвет ковидной конспирологии демонстрирует значимость экспертного знания в общественно-политических процессах. Этический компонент в публичной деятельности ученых особенно важен для противодействия продвижению теорий заговора. На этом направлении содержится значительный нереализованный потенциал, который необходимо использовать для формирования общественного сознания, устойчивого к конспирологии. Прививка для разума, которую могут дать политологи и другие ученые-гуманитарии, сегодня не менее важна, чем вакцинация и соблюдение иных профилактических мер от COVID-19.

Исследование выполнено при финансовой поддержке РФФИ в рамках научного проекта № 20-04-60109 «Воздействие глобальных биогенных угроз на мировую политику».

\section{Список литературы}

Михеев Е.А., Нестик Т.А. 2021. Психологические механизмы инфодемии и отношение личности к дезинформации о COVID-19 в социальных сетях. Институт психологии Российской академии наук. Социальная и экономическая психология. Т. 6. № 1(21). С. 37-64.

Мягков М.Г., Кубрак Т.А., Латынов В.В., Мундриевская Ю.О. 2021. Пандемия COVID-19 и конспирологические убеждения: психологические предпосылки, последствия, возможности коррекции. - Вестник Томского государственного университета. № 467. С. 156163.

Панченко А.А. 2015. Антропология и конспирология. - Антропологический форум. № 27. С. 89-94.

Хохлов А.А. 2020. Конспирологические теории как феномен медиавоздействия на общественное сознание. - Вестник РГГУ. Сер. Философия. Социология. Искусствоведение. № 1. С. 96-104.

Чугров С.В. 2017. Post-truth: трансформация политической реальности или саморазрушение либеральной демократии? - Полис. Политические исследования. № 2. С. 42-59.

1 Теории заговора - и что люди о них думают? - ВЦИОМ. 29.07.2020. Доступ: https:// wciom.ru/analytical-reviews/analiticheskii-obzor/teorii-zagovora-i-chto-lyudi-o-nikh-dumayut (проверено 23.01.2022). 
Harambam J. 2020. Contemporary Conspiracy Culture. Truth and Knowledge in an Era of Epistemic Instability. London: Routledge. 254 p.

Routledge Handbook of Conspiracy Theories. $1^{\text {st }}$ ed. (ed. by M. Butter, P. Knight). 2020. London: Routledge, 700 p.

The Social Psychology of Gullibility: Fake News, Conspiracy Theories, and Irrational Beliefs. $1^{\text {st }}$ ed. (ed. by J.P. Forgas, R.F. Baumeister). 2019. N.Y.: Routledge. 352 p.

ARTEEV Sergey Pavlovich, Cand.Sci. (Pol.Sci.), Lecturer at the Moscow State Institute of International Relations, University of the Ministry for Foreign Affairs of Russia (76 Vernadskogo Ave, Moscow, Russia, 119454); Research Fellow at the Primakov Institute of World Economy and International Relations, Russian Academy of Sciences (23 Profsojuznaja St, Moscow, Russia, 117997; artsp7@yandex.ru)

\title{
COVID-19 PANDEMIC: CONSPIRACY AND ANTI-CONSPIRACY
}

\begin{abstract}
Today the world faces not only a biogenic challenge, but also a challenge in the media sphere, which has a direct impact on the situation with the spread of the COVID-19. Despite the fact that conspiracy became one of the most discussed topics in the public discourse long before 2020, conspiracy as a phenomenon in the humanities and social sciences is studied primarily in anthropology, sociology and psychology. Meanwhile, the COVID-19 pandemic clearly demonstrates that conspiracy theory (CT) has become one of the main political factor. Western political science discourse reacted to the request faster. At the turn of the 2010s-2020s, there was an intensification in this direction, the research field of conspiracy in political science began to form. Russian research discourse about it is still small and fragmented. The aim of the paper is to fill this gap. The text attempts to answer the research question: why have COVID conspiracy theories managed to gain such popularity and how do they prolong the pandemic by influencing political processes? For this purpose, the author analyzes conspiracy prerequisites (evolutionary atavism, information storm, non-transparent policy, epistemological limitations of human being, popular culture); gives the typology of CT (1. Does the virus really exist? 2. COVID-19 is no more dangerous than the flu. 3. Who is guilty? 4. Who is the beneficiary of the pandemic? 5. Is vaccination a microchipping?); and proposes measures to neutralize the harmful effects of CT on public consciousness. At the same time, the author opposes prohibitive measures as the least effective ways to combat conspiracy.
\end{abstract}

Keywords: conspiracy theory, pandemic, COVID-19, vaccination, chipping 